\title{
ETIKA BISNIS ISLAM: TEORI DAN APLIKASI PADA PERUSAHAAN MANUFAKTUR
}

\author{
Laili Latifah Puspitasari
}

\author{
Fakultas Ekonomi, Universitas Islam Negeri Maulana Malik Ibrahim Malang \\ Jl. Gajayana 50 Malang Telp. 0341-551354 \\ Email: tifapuspita@gmail.com
}

Abstract

The business world can't be separated from business ethics. Many research results indicate apositive relationship between business ethics and corporate success. So far, dishonest business practices, which is only concern of the maximum benefit and cause negative effect for other will lead to company breaking, even a big company. Become aware of business ethic, people began to emphasize the importance of relationship factorsin business ethics. So the purpose of this research was to analyze the application of Islamic business ethicson profitability of RumahYoghurt based on employee prespective. This research used a qualitative descriptive approach, which systematically describes the focus of research on the relationship of the application of Islamic business ethics on profitability of the company based on employee perspective. Research subjects were 30 employees Rumah Yoghurt. Analysis of the data conducting in four stages: data collection, data reduction, data presentation, and conclusion. The results showed that the islamic bussiness ethics which was adopted by Rumah Yoghurt become the effective way in improving profitability of the company. It was proven by the average overall score of high employee questionnaire results, both on the ethical a spects of management, marketing ethics, and environmental ethic. Running its business and operations, rumah yoghurt has islamic bussiness ethic standart which become guideline for entire business activities and operations. Implementation of those standart properly will lead to profitability increase.

Keywords: Islamic Business Ethics, Management Ethics, Marketing Ethics, Environmental Ethics 
Abstrak

Dunia bisnis tidak bisa dilepaskan dari etika bisnis. Banyak hasil penelitian menunjukkan adanya hubungan positif antara etika bisnis dan kesuksesan perusahaan. Pada akhirnya praktek bisnis yang tidak jujur, hanya memikirkan keuntungan maksimal dan merugikan pihak lain akan membawa perusahaan besar sekalipun akan hancur. Bersama dengan semakin besarnya kesadaran etika dalam berbisnis, orang mulai menekankan pentingnya keterkaitan faktor-faktor etika dalam bisnis. Maka tujuan dari penelitian ini adalah analisis penerapan etika bisnis Islam terhadap tingkat profitabilitas Rumah Yoghurt berdasarkan perspektif karyawan. Penelitian ini menggunakan pendekatan kualitatif deskriptif, yang menggambarkan secara sistematis tentang fokus penelitian yaitu hubungan penerapan etika bisnis Islam dengan tingkat profitabilitas perusahaan berdasarkan perspektif karyawan. Subjek penelitian merupakan 30 orang karyawan Rumah Yoghurt. Analisis data melalui empat tahap, yaitu: pengumpulan data, reduksi data, penyajian data, dan penarikan kesimpulan. Pengumpulan data menggunakan metode penyebaran kuisioner, wawancara, observasi, dan dokumentasi. Dari hasil penelitian menunjukkan bahwa etika bisnis Islam yang diterapkan oleh Rumah Yoghurt dinilai oleh mayoritas karyawan efektif dalam meningkatkan profitabilitas perusahaan. Hal tersebut dibuktikan dari keseluruhan rata-rata skor hasil kuisioner karyawan yang tinggi, baik pada aspek etika manajemen, etika pemasaran, maupun etika lingkungan. Dalam menjalankan kegiatan usaha dan operasionalnya, Rumah Yoghurt memiliki standar pedoman etika bisnis Islam yang dijadikan landasan seluruh kegiatan usaha dan operasional perusahaan. Apabila perusahaan dapat menerapkan pedoman etika bisnis Islam tersebut dengan baik dan secara berkelanjutan, maka diyakini oleh sebagian besar karyawan, tingkat profitabilitas perusahaan akan meningkat.

Kata kunci: Etika Bisnis Islam, etika manajemen, etika pemasran, etika lingkungan

\section{PENDAHULUAN}

Kesadaran umat muslim untuk kembali ke ajaran Qur'an dan Hadits, memunculkan pemikiran untuk menggunakan sistem ekonomi yang berdasarkan pada syariah Islam atau disebut sebagai sistem ekonomi Islam. Kesadaran mereka muncul karena ternyata sistem ekonomi yang dijalankan selama ini tidak menyebabkan kondisi ekonomi global semakin membaik. Sistem ekonomi kapitalis telah menumbuhkan budaya persaingan bebas antar sesama pelaku ekonomi, bersikap individualis dan hedonisme yang tinggi, hal tersebut bertolak belakang dengan semangat solidaritas Islam yang menjunjung tinggi pemerataan pendapatan serta pemerataan kesempatan kerja. Kesadaran inilah yang menyebabkan munculnya ekonomi syariah sebagai jawaban atas permasalahan yang dihadapi negara-negara muslim. Apalagi sistem ekonomi Islam jaman Nabi SAW dan para sahabatnya terbukti memunculkan kejayaan Islam. 
Munculnya kesadaran untuk menjalankan syariah Islam dalam kehidupan ekonomi muslim berarti harus mengubah pola pikir dari sistem ekonomi kapitalis ke sistem ekonomi syariah termasuk dalam dunia bisnis. Dunia bisnis tidak bisa dilepaskan dari etika bisnis. Banyak hasil penelitian yang menunjukkan adanya hubungan yang positif antara etika bisnis dan kesuksesan suatu perusahaan. Pada akhirnya praktek bisnis yang tidak jujur, hanya memikirkan keuntungan maksimal dan merugikan pihak lain akan membawa perusahaan, yang tergolong raksasa sekalipun akan hancur juga. Etika bisnis sebenarnya bukan fenomena dan kajian yang baru. Sejak abad ke-18 hingga kini, hubungan etika dan bisnis telah banyak diperdebatkan. Bisnis yang melibatkan praktek-praktek kecurangan, penipuan dan lain-lain adalah alasan etika bisnis mendapat perhatian yang intensif hingga menjadi kajian tersendiri. Masalah etika bisnis muncul bila terjadi suatu konflik tanggung jawab kepentingan atau dilema memilih antara yang benar dan yang salah, yang salah dengan yang lebih salah atau mempertimbangkan sesuatu yang lebih kompleks yang diakibatkan oleh aktivitas bisnis (Ernawan, 2007:54)

Perilaku bisnis yang tidak beretika terjadi pada hampir semua negara, misalnya perusahaan Nike membayar upah pekerja yang rendah di berbagai negara berkembang untuk membuat sepatu yang berharga tinggi. Di Indonesia, praktek bisnis yang tidak beretika dicontohkan dengan adanya kasus obat anti nyamuk HIT, di mana PT Megahsari Makmur ketahuan memakai bahan pestisida yang bisa menyebabkan kanker pada manusia di dalam produk barunya, walau zat tersebut sudah dilarang penggunaannya sejak tahun 2004 (Ernawan, 2007:56). Di samping itu, ada juga perusahaan yang melaksanakan etika bisnis dalam praktek bisnisnya. Seperti yang disampaikan Ernawan (2007:56), yang terjadi pada biskuit Arnotts di Australia. Pada suatu saat perusahaan ditelpon oleh seseorang yang hendak memeras perusahaan tersebut dengan mengatakan bahwa salah satu kemasan produknya berisi biskuit yang beracun dan tidak diketahui kecuali oleh si pemeras tersebut. Perusahaan dihadapkan pada dua pilihan yaitu membayar orang yang memeras tersebut untuk menunjukkan produk mana yang beracun, atau menarik seluruh peredaran biskuit tersebut. Namun perusahaan lebih memilih untuk menanggung kerugian yang besar dengan menarik seluruh produk-produknya dan memusnahkannya. Ternyata hal tersebut menanamkan kepercayaan konsumen kepada perusahaan. walaupun pada saat itu perusahaan menanggung kerugian yang cukup besar, namun ternyata enam bulan kemudian pendapatan perusahaan naik tiga kali lipat. Contoh kasus yang terjadi di Indonesia terjadi pada kasus Ajinomoto, di mana saat dinyatakan oleh MUI bahwa produknya tidak halal, Ajinomoto menarik semua produknya dan perusahaan pun menanggung banyak kerugian. Namun dengan mengindahkan himbauan dari MUI dan dengan melakukan pendekatan dengan para ulama, kinerja keuangan yang semula menurun tajam lama kelamaan naik.

Bersama dengan semakin besarnya kesadaran etika dalam berbisnis, orang mulai menekankan pentingnya keterkaitan faktor-faktor etika dalam bisnis. 
Sesungguhnya dalam hal seluruh pelaksanaan kehidupan telah diatur dalam pandangan ajaran Agama Islam untuk mengatur seluruh kehidupan manusia termasuk dalam kaitannya pelaksanaan perekonomian dan bisnis. Dalam ajaran Islam memberikan kewajiban bagi setiap muslim untuk berusaha semaksimal mungkin untuk melaksanakan syariah (aturan). Islam di segala aspek kehidupan termasuk di dalamnya aturan bermuamalah (usaha dan bisnis) yang merupakan jalan dalam rangka mencari kehidupan.

Pada hakikatnya tujuan penerapan aturan (syariah) dalam ajaran Islam di bidang muamalah tersebut khususnya perilaku bisnis adalah agar terciptanya pendapatan (rizki) yang berkah dan mulia, sehingga akan mewujudkan pembangunan manusia yang berkeadilan dan stabilisasi untuk mencapai pemenuhan kebutuhan, kesempatan kerja penuh dan distribusi pendapatan yang merata tanpa harus mengalami ketidakseimbangan yang berkepanjangan di masyarakat. Penerapan etika bisnis Islam tersebut juga harus mampu dilaksanakan dalam setiap kegiatan perekonomian.

Etika bisnis yang diterapkan Arnotts maupun Ajinomoto seperti telah dicontohkan di atas, secara tidak langsung menjadi alat marketing baru bila dilakukan secara berkelanjutan. Masyarakat sekarang lebih pintar dalam memilih produk yang akan mereka konsumsi. Sekarang, masyarakat cenderung untuk memilih produk yang diproduksi oleh perusahaan yang peduli terhadap lingkungan dan atau melaksanakan Corporate Sosial Responsibility (CSR). Banyak manfaat yang diperoleh perusahaan dengan melaksanakan etika bisnis, antara lain produk semakin disukai oleh konsumen dan perusahaan diminati investor. Dengan menerapkan etika bisnis, citra perusahaan akan semakin baik sehingga loyalitas konsumen semakin tinggi. Seiring meningkatnya loyalitas konsumen dalam waktu yang lama, maka penjualan perusahaan akan semakin membaik, dan pada akhirnya diharapkan tingkat profitabilitas perusahaan juga meningkat.

Dewasa ini suatu perusahaan dikatakan maju apabila kinerja finansialnya baik, yang dilihat dari tingkat profitabilitas perusahaan tersebut. Dalam etika bisnis Islam, manusia dianjurkan tidak hanya mencari untung sebanyak-banyaknya namun lebih mencari rezeki yang berkah. Tujuan bisnis tidak hanya mencari laba (profit), tetapi juga mensejahterakan orang (people), dan menjamin keberlanjutan hidup planet ini. Global Compact Initiative menyebut pemahaman ini dengan 3P (profit, people, planet), yaitu (Nugroho, 2007 dalam Dahli dan Siregar, 2008).

Menurut Harahap (2011:102) ada beberapa indikator yang dapat digunakan untuk mengukur etika bisnis Islam, diantaranya ialah: etika manajemen, etika produksi, etika pemasaran, dan etika lingkungan. Apabila keempat aspek tersebut dilaksanakan secara tepat dapat menciptakan lingkungan perusahaan yang kondusif, yang menyebabkan kinerja karyawan menjadi baik. Dimana kinerja karyawan menjadi salah satu faktor meningkatnya produktivitas karyawan yang berdampak pada produk yang dihasilkan. Sehingga dapat dikatakan bahwa, dengan menerapkan etika bisnis Islam secara tepat, tingkat profitabilitas perusahaan dapat meningkat. 
Permasalalahan dalam penelitian ini adalah bagaimanakah praktik kegiatan usaha dan operasional Rumah Yoghurt yang berlandaskan pada etika bisnis Islam? Bagaimanakah pengaruh penerapan etika bisnis Islam terhadap tingkat profitabilitas pada periode berjalan menurut perspektif karyawan Rumah Yoghurt?

\section{Kajian Teoritis}

\section{Etika Bisnis Dalam Islam}

Menurut Djakfar (2007:20) "bagaimanapun perilaku mencerminkan akhlak (etika) seseorang atau dengan kata lain, perilaku berealisasi dengan etika. Apabila seseorang taat pada etika, berkecenderungan akan menghasilkan perilaku yang baik dalam setiap aktivitas atau tindakannya, tanpa kecuali dalam aktivitas bisnis". Menurut Qardawi (2001) dalam Djakfar (2007:22), antara ekonomi (bisnis) dan akhlak (etika) tidak pernah terpisah sama sekali, seperti halnya antara ilmu dan akhlak, antara politik dan akhlak, dan antara perang dan akhlak. Akhlak adalah daging dan urat nadi kehidupan Islami. Karena risalah Islam adalah risalah akhlak. Sebagaimana pula tidak pernah terpisah antara agama dan negara, dan antara materi dan rohani. Seorang muslim yakin akan kesatuan hidup dan kesatuan kemanusiaan. Sebab itu tidak bisa diterima sama sekali tindakan pemisahan antara kehidupan dunia dan agama sebagaimana yang terjadi di Eropa.

Titik sentral etika Islam adalah menentukan kebebasan manusia untuk bertindak dan bertanggungjawab karena kepercayaannya terhadap kemahakuasaan Tuhan. Hanya saja kebebasan manusia itu tidaklah mutlak, dalam arti, kebebasan yang terbatas. Dalam skema etika Islam, manusia adalah pusat penciptaan Tuhan. Manusia merupakan wakil Tuhan di muka bumi sebagaimana firman-Nya dalam Q.S Al-An'am 195:

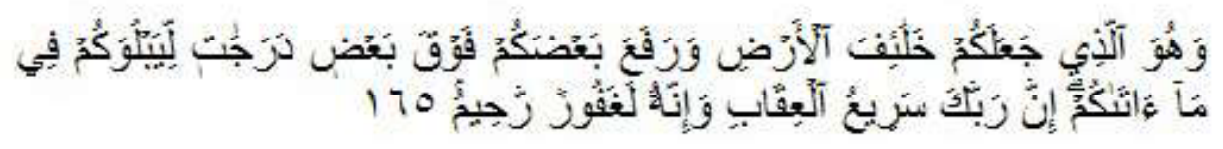

"Dan Dialah yang menjadikan kamu penguasa-penguasa di bumi dan Dia meninggikan sebahagian kamu atas sebahagian (yang lain) beberapa derajat, untuk mengujimu tentang apa yang diberikan-Nya kepadamu. Sesungguhnya Tuhanmu amat cepat siksaan-Nya dan sesungguhnya Dia Maha Pengampun lagi Maha Penyayang."

Karena itu, seluruh tujuan hidup manusia adalah untuk mewujudkan kebajikan kekhalifahannya sebagai pelaku bebas karena dibekali kehendak bebas, mampu memilih antara yang baik dan jahat, antara yang benar dan yang salah, antara yang halal dan yang haram. Dengan kata lain, manusia akan mempertanggungjawabkan 
pilihan-pilihan yang diambilnya dalam kapasitasnya sebagai individu. (Djakfar, 2007:11)

\section{Prinsip Dasar Etika Islam dan Prakteknya Dalam Bisnis}

Menurut Beekun (1997:21), Islam memiliki enam aksioma dari filsafat etika Islam, yaitu:

\section{Tauhid, unity (kesatuan, keutuhan)}

Ini adalah konsep tauhid yang berarti semua aspek dalam hidup dan mati adalah satu, baik aspek politik, ekonomi, sosial, maupun agama adalah berasal dari satu sistem nilai yang saling terintegrasi, terkait, dan konsisten. Menurut alGhazali dalam Nawatmi (2010:58), adapun prakteknya dalam bisnis:

a. Tidak ada diskriminasi baik terhadap pekerja, penjual, pembeli, serta mitra kerja lainnya sesuai dengan firman-Nya dalam surat Al Hujurat:13:

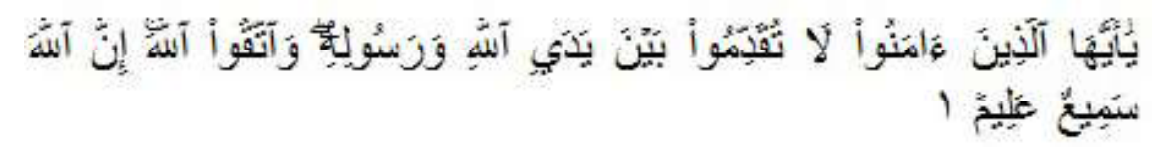

"Hai manusia, sesungguhnya Kami menciptakan kamu dari seorang laki-laki dan seorang perempuan dan menjadikan kamu berbangsabangsa dan bersuku-suku supaya kamu saling kenal-mengenal. Sesungguhnya orang yang paling mulia diantara kamu disisi Allah ialah orang yang paling takwa diantara kamu. Sesungguhnya Allah Maha Mengetahui lagi Maha Mengenal."

b. Terpaksa atau dipaksa untuk menaati Allah SWT, sesuai dengan firmanNya dalam surat Al-An'am:163 yang berbunyi:

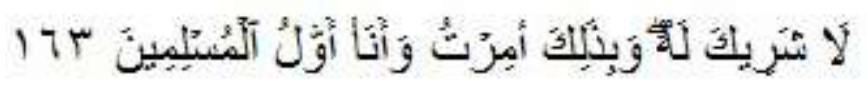

"Tiada sekutu bagi-Nya; dan demikian itulah yang diperintahkan kepadaku dan aku adalah orang yang pertama-tama menyerahkan diri (kepada Allah)."

c. Meninggalkan perbuatan yang tidak beretika dan mendorong setiap individu untuk bersikap amanah karena kekayaan yang ada merupakan amanah Allah.

\section{Adil, ekuilibrium (keseimbangan, harmoni)}

Semua aspek kehidupan harus seimbang agar dapat menghasilkan keteraturan dan keamanan sosial sehingga kehidupan manusia di dunia ini dan di akhirat nanti melahirkan harmoni dan keseimbangan. Menurut al-Ghazali dalam Nawatmi (2010:58), adapun prakteknya dalam bisnis: 
a. Tidak ada kecurangan dalam takaran dan timbangan.

b. Penentuan harga berdasarkan mekanisme pasar yang normal.

\section{Freewill (kebebasan)}

Manusia diangkat sebagai khalifah Allah atau pengganti Allah di bumi untuk memakmurkannya. Manusia dipersilahkan dan mampu berbuat sesuka hatinya tanpa paksaan, Tuhan memberikan koridor yang boleh dan yang tidak boleh. Aturan itu dimaksudkan untuk kemaslahatan manusia. Allah menurunkan RasulNya untuk memberikan peringatan dan kabar gembira. Pelanggaran terhadap aturan Allah akan dimintai pertanggungjawaban. Menurut al-Ghazali dalam Nawatmi (2010:58), adapun aplikasinya dalam bisnis:

a. Konsep kebebasan dalam Islam lebih mengarah pada kerja sama, bukan persaingan apalagi sampai mematikan usaha satu sama lain. Kalaupun ada persaingan dalam usaha maka, itu berarti persaingan dalam berbuat kebaikan atau fastabiq al-khairat (berlomba-lomba dalam kebajikan).

b. Menepati kontrak, baik kontrak kerja sama bisnis maupun kontrak kerja dengan pekerja.

\section{Responsibility (pertanggungjawaban)}

Karena kebebasan yang diberikan di atas, manusia harus memberikan pertanggungjawabannya nanti di hadapan Allah atas segala keputusan dan tindakan yang dilakukannya. Menurut al-Ghazali dalam Nawatmi (2010:58), adapun aplikasinya dalam bisnis:

a. Upah harus disesuaikan dengan UMR (upah minimum regional).

b. Economic return bagi pemberi pinjaman modal harus dihitung berdasarkan perolehan keuntungan yang tidak dapat dipastikan jumlahnya dan tidak bisa ditetapkan terlebih dahulu seperti dalam sisitem bunga.

c. Islam melarang semua transaksi alegotoris seperti gharar, sistem ijon, dan sebagainya.

\section{Ihsan, benevolence (kemanfaatan)}

Semua keputusan dan tindakan harus menguntungkan manusia baik di dunia maupun di akhirat, selain hal itu seharusnya tidak dilakukan. Islam tidak membenarkan setiap tindakan yang dapat menimbulkan kerusakan terhadap diri, masyarakat, bahkan makhluk lain seperti binatang, tumbuhan, dan alam. Menurut al-Ghazali dalam Nawatmi (2010:58), adapun aplikasinya dalam bisnis ialah:

a. Memberikan zakat dan sedekah.

b. Memberikan kelonggaran waktu pada pihak terutang dan bila perlu mengurangi beban utangnya.

c. Menerima pengembalian barang yang telah dibeli.

d. Membayar utang sebelum penagihan datang.

e. Adanya sikap kesukarelaan antara kedua belah pihak yang melakukan transaksi, kerja sama atau perjanjian bisnis. 
f. Adanya sikap ramah, toleran, baik dalam menjual, membeli dan menagih utang.

g. Jujur dalam setiap proses transaksi bisnis.

h. Memenuhi perjanjian atau transaksi bisnis.

\section{Aspek Etika Bisnis Islam}

\section{Etika Manajemen}

Menurut Harahap (2011:103) Dalam perusahaan, pihak yang bertanggung jawab pada kegiatan bisnis adalah manajemen sehingga sukar memisahkan antara manajemen dengan perusahaan. Sebagai suatu entitas, perusahaan dianggap dapat memiliki hak hidup sendiri sebagaimana seorang manusia. Namun, belakangan ini, sikap itu dinilai berbahaya karena kecenderungan perusahaan dikedepankan dan manajemen serta pemilik yang menahkodai dari belakang berlindung di balik entitas jika melakukan hal-hal yang secara etis tidak dibenarkan jika dilakukan seorang manusia. Jadi, banyak kegiatan perusahaan yang semakin jauh dari kepentingan sosial dan hanya untuk mengejar keuntungan sesaat.

Dalam Islam, secara jelas dan tegas, manusialah yang menjadi pengganti dan wakil Allah SWT. di muka bumi ini untuk memakmurkannya sesuai dengan aturan dan ketentuan Allah SWT. Islam menempatkan semua dalam satu kesatuan yang tidak terpisahkan satu sama lain atau integrated. Ini mengharuskan agar semua lembaga, organisasi, atau badan hukum boleh saja didirikan, tetapi harus ada "sang mukalaf" yang menjadi penanggungjawab yang secara hukum dunia dan akhirat bertanggungjawab terhadap semua kegiatan perusahaan. (Harahap, 2011:104)

Menurut Djakfar (2007:13) peran integrasi dalam konsep tauhid akan menimbulkan perasaan dalam diri manusia bahwa ia akan selalu merasa direkam segala aktivitas kehidupannya, termasuk dalam aktivitas berekonomi. Sesuai dengan firmanNya dalam surat An-Nahl 90:

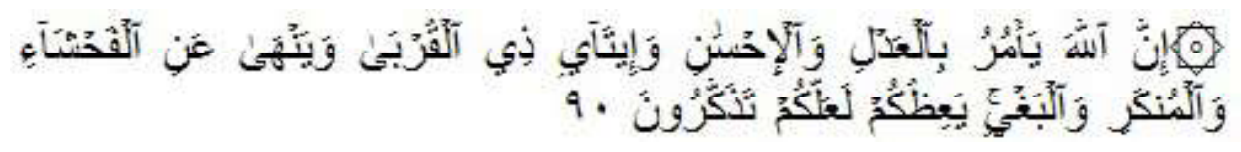

"Sesungguhnya Allah menyuruh (kamu) berlaku adil dan berbuat kebajikan, memberi kepada kaum kerabat, dan Allah melarang dari perbuatan keji, kemungkaran dan permusuhan. Dia memberi pengajaran kepadamu agar kamu dapat mengambil pelajaran"

Karena manajemen lahir dari masyarakat Amerika dan memiliki filosofi sekuler, bagi orang Islam, filsafat dan nilai yang ada di dalamnya banyak yang tidak sesuai dengan keyakinan umat Islam. Oleh karena itu, para ahli dari kalangan Islam mencoba mempelajari manajemen yang sesuai dengan tata nilai Islam. Misalnya Effendy (1986) dalam Harahap (2011:105) mengemukakan empat prinsip manajemen Islami: 
1. Prinsip amar makruf nahi munkar,

2. Kewajiban menegakkan kebenaran,

3. Menegakkan keadilan,

4. Kewajiban menyampaikan amanat.

Beberapa fungsi-fungsi manajerial menurut Baidan (2007:77) ialah sebagai berikut:

\section{Motivasi}

Dalam memberi motivasi umat untuk berbuat sesuatu bahkan untuk beriman pun Allah tidak langsung memerintahkan mereka, melainkan menyentuh perasaan mereka, dan merangsang pemikiran rasional mereka. Untuk maksud itu dalam berkomunikasi dengan mereka Allah menggunakan bahasa yang indah dengan nilai sastra yang amat tinggi sehingga para pujangga Arab terkagum-kagum mendengar ayat-ayat Al Quran yang dibacakan Rasul. Dengan cara memotivasi yang sangat halus serupa itu, maka banyaklah menarik perhatian umat lalu mereka menyatakan masuk Islam dengan sukarela, sedikit pun tidak ada paksaan (Q.S Al-Baqarah: 256; Yunus:99)

Seandainya seorang manajer mau mengikuti pola yang diterapkan Al Quran dalam memberikan motivasi kepada para stafnya, tentu mereka akan sangat tertarik dalam bekerja dan lebih merasakan sense of belonging serta bertanggung jawab penuh terhadap tugas-tugas yang dipercayakan kepadanya.

\section{Komunikasi}

Tugas manajer yang tak kalah pentingnya ialah berkomunikasi, bahkan boleh disebut komunikasi merupakan urat nadi bagi berkiprahnya suatu organisasi, apalagi organisasi bisnis, salah sedikit saja berkomunikasi bisa membuat hancurnya sebuah usaha. Dalam hal ini Allah mengingatkan Nabi Muhammad SAW;"Sekiranya kamu berkata kasar kepada mereka dan berhati keras (tidak santun), niscaya mereka akan lari dari sisimu." (Q.S. Ali Imran:159) Berkata santun dan lemah lembut merupakan prasyarat pertama dan utama jika ingin komunikasi efektif dan mencapai sasaran. Jadi masalah komunikasi sangat penting demi membuat suatu organisasi atau bisnis memiliki lingkungan yang kondusif.

\section{Pengawasan (kontrol)}

Melakukan pengawasan adalah suatu keharusan karena cetak biru manusia itu memang mempunyai potensi untuk berbuat baik dan buruk, berlaku jujur dan curang, dan sebagainya. Bila salah satu fungsi manajemen melakukan kontrol, maka hal itu sesuai dengan sistem manajemen yang diterapkan Allah dalam mengatur hidup dan kehidupan di muka bumi ini, bahkan pengawasan Allah tidak tanggung-tanggung mulai dari menugaskan diri yang bersangkutan (Q.S. Yasin:65; Fushshilat:20-21), benda di sekitarnya, sampai para malaikat terlibat dalam mengawasi seseorang (Q.S. al-An'am:17; Yusuf:26; Qaf:15). 


\section{Perencanaan}

Posisi perencanaan dalam suatu sistem manajemen boleh disebut sebagai kompas yang akan menuntun proses dan perjalanan sebuah program sehingga tidak terjadi salah arah dalam mencapai tujuan atau target yang telah ditetapkan. Kalau diperhatikan alam raya ini, betapa sangat teraturnya, sehingga tidak pernah terjadi kekacauan sedikit pun, semuanya berjalan sesuai alurnya masingmasing (Q.S. al-Anbiya':33; Yasin:40). Jelas mustahil alam yang demikian luas dan sangat teratur itu akan tercipta tanpa perencanaan yang matang.

\section{Etika Pemasaran}

Dalam pandangan Islam, setiap individu maupun kelompok, di satu sisi, diberikan kebebasan untuk mendapatkan keuntungan sebesar-besarnya, namun di sisi lain, ia terikat dengan iman dan etika sehingga ia tidak bebas mutlak dalam menginvestasikan modalnya (berbisnis) atau membelanjakan hartanya. (Djakfar, 2007:82). Dalam kajian fiqih Islam, kebenaran dan keakuratan informasi ketika seorang pelaku usaha mempromosikan barang dagangannya menempati kajian yang sangat signifikan. Islam tidak mengenal sebuah istilah kapitalisme klasik yang berbunyi "ceveat emptor" atau "let the buyer beware" (pembelilah yang harus berhati-hati), tidak pula "ceveat venditor" (pelaku usahalah yang harus berhati-hati). Tetapi dalam Islam yang berlaku adalah prinsip keseimbangan ( $\left.a l-t a{ }^{\prime} a d u l\right)$ atau ekuilibrium di mana pembeli dan penjual harus berhati-hati di mana hal itu tercermin dalam teori perjanjian (nazhariyyat al-'uqud) dalam Islam. (Djakfar, 2007:83)

Salah satu sebab cacatnya rasa saling rela (taradhin) adalah tidak adanya kesesuaian antara sifat atau kriteria barang yang disampaikan penjual pada pembeli atau yang diharapkan oleh pembeli sehingga timbul penyesalan sebagai tanda dari rusaknya rasa saling rela. (Djakfar, 2007:84). Dalam praktik dagang sederhana (skala kecil), untuk melariskan barang dagangannya, seorang pedagang kadangkala tidak segan-segan bersumpah. Sangat banyak ayat Al Quran yang menyinggung tentang penyampaian informasi yang tidak benar pada orang lain, di antaranya surat Ali Imran ayat 77 tentang pelarangan promosi yang tidak sesuai dengan kualisifikasi barang, yang berbunyi:

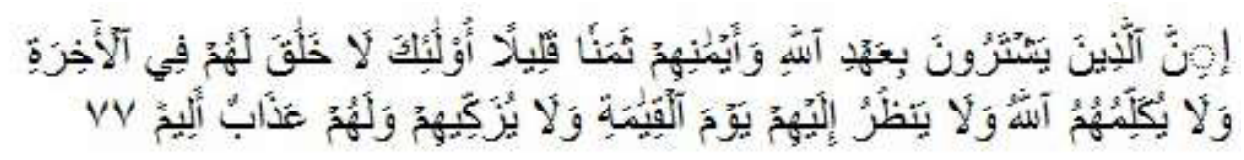

"Sesungguhnya orang-orang yang menukar janji (nya dengan Allah) dan sumpah-sumpah mereka dengan harga yang sedikit, mereka itu tidak mendapat kebahagiaan (pahala) di akhirat, dan Allah tidak akan berkatakata dengan mereka dan tidak akan melihat kepada mereka pada hari kiamat dan tidak (pula) akan mensucikan mereka. Bagi mereka azab yang pedih." 
Landasan etika dalam periklanan dapat dikemukakan bahwa:

1. Berbisnis bukan hanya mencari keuntungan, tetapi itu harus diniatkan sebagai ibadah kita kepada Allah SWT,

2. Sikap jujur (objektif),

3. Sikap toleransi antar penjual dan pembeli,

4. Tekun (istiqomah) dalam menjalankan usaha,

5. Berlaku adil dan melakukan persaingan sesama pebisnis dengan baik dan sehat. Dengan demikian dalam Islam bagaimana pun periklanan harus memperhatikan nilai-nilai etis agar tidak menyesatkan konsumen. Dalam hal ini pelaku bisnis harus bersikap jujur (objektif) dan adil, tidak hanya mengejar keuntungan sepihak, sementara pihak lain menjadi korban karena akibat iklan yang tidak transparan. (Djakfar, 2007:86).

\section{Etika Lingkungan}

Menurut Djakfar (207:149), tanggung jawab moral bisnis, implementasinya bisa pada tanggung jawab sosial. Bahkan yang tidak kalah pentingnya tanggung jawab pada lingkungan alam. Dari sejumlah tanggung jawab itu sebenarnya yang paling krusial adalah tanggung jawab pada diri sendiri dan kepada Tuhan. Islam di satu sisi mendorong agar manusia mengelola alam guna memenuhi segala kebutuhannya, namun di sisi lain Islam sangat menentang perusakan alam dalam segala cara dan bentuknya. Di sinilah arti penting perlu adanya kesadaran bahwa aktivitas bisnis yang mengelola alam perlu berpijak pada norma-norma etis, khususnya yang bersumber dari ajaran wahyu, yakni Alquran dan Hadits. Seperti pada firman-Nya dalam surat Al-Mulk ayat 15:

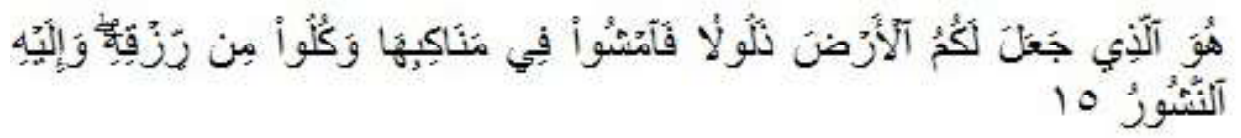

"Dialah Yang menjadikan bumi itu mudah bagi kamu, maka berjalanlah di segala penjurunya dan makanlah sebahagian dari rezeki-Nya. Dan hanya kepada-Nya-lah kamu (kembali setelah) dibangkitkan."

Menurut Muhammad (2002:193), selain harus bertanggung jawab kepada berbagai pihak yang berkepentingan dalam usahanya dan lingkungan alam sekelilingnya, kaum muslimin dan organisasi tempat bekerja juga diharapkan memberi perhatian terhadap kesejahteraan umum masyarakat dimana mereka tinggal. Sebagai bagian masyarakat, pengusaha muslim harus turut memperhatikan kesejahteraan anggotanya yang miskin dan lemah. Pahala memelihara kaum lemah dan papa ditekankan dalam hadis di bawah ini:

"Rasulullah saw berkata, "Orang yang merawat dan berbuat sesuatu untuk para janda dan orang-orang papa, adalah laksana seorang ksatria 
yang berjuang karena Allah Swt, atau laksana orang yang berpuasa sepanjang siang dan beribadah sepanjang malam."

Akhirnya, berbeda dengan hukum sekuler, Islam tidak mengakui keberadaan sebuah usaha sebagai entitas perusahaan legal yang pemiliknya tidak bertanggung jawab secara pribadi terhadap berbagai masalah yang diciptakannya. Karenanya, jika sebuah usaha menciptakan masalah, maka pemiliknya harus siap untuk menyelesaikannya. (Muhammad, 2002:195)

Salah satu bentuk tanggung jawab sosial perusahaan terhadap lingkungan sosial ialah seperti terlibat dalam berbagai agenda sosial yang dilakukan oleh McDonalds. Di mana dengan terlibat dalam berbagai agenda sosial maka akan semakin meningkatkan nilai positif perusahaan tersebut. Dukungan sponsor McDonalds terhadap anak-anak yang membutuhkan bantuan melalui program Ronald McDonalds telah meningkatkan citra perusahaan tersebut sebagai perusahaan yang peduli terhadap masalah anak-anak. Seperti etika bisnis pada Nestle yang dicontohkan oleh Nawatmi (2010), di mana Nestle di India membantu para peternak sapi sehingga produksi susu per peternak meningkat 50 kali lipat dan taraf hidup para peternak juga meningkat.

\section{METODE PENELITIAN}

Analisis data dalam penelitian ini menggunakan metode deskriptif kualitatif, yaitu analisis data yang berbentuk rangkaian kata atau kalimat dimana dari kalimat tersebut akan diperoleh suatu kesimpulan dengan melakukan pendekatan, baik secara teoritis maupun pemikiran yang logis untuk memecahkan masalah secara lengkap. Adapun tahapan analisis data dilaksanakan dengan: Pengumpulan data, Reduksi data, Penyajian data, dan pengambilan keputusan

\section{PEMBAHASAN}

Aplikasi Etika Bisnis Islam Perusahaan yang terdiri dari: etika manajemen, etika pemasaran, dan etika lingkungan dapat diurakian sebagai berikut:

\section{Etika Manajemen}

Rumah Yoghurt memiliki beberapa pedoman dalam menerapkan etika manajemen perusahaannya, yaitu: 
Tabel 1. Pedoman Etika Manajemen

\begin{tabular}{ll}
\hline No & Keterangan \\
\hline 1 & Menerapkan manajemen yang jujur dan amanah sesuai syariat \\
2 & Melaksanakan amar makruf nahi munkar dalam lingkungannya \\
3 & Menciptakan suasana terbuka, transparan, dan bertanggung jawab \\
4 & Mengelola dana dan sumber kekayaan secara efisien \\
5 & Harus selalu melakukan perbaikan \\
6 & Menciptakan lingkungan atau budaya bisnis yang sesuai syariat \\
7 & Menerapkan praktik manajemen sumber daya manusia yang adil, \\
& memberikan hak-hak pekerja, dan memberikan reward berdasarkan kinerja, \\
8 & Mema, kreasi dan keunggulan \\
\hline
\end{tabular}

Sumber: Rumah Yoghurt Kota Batu, 2010

Manajemen berfungsi sebagai penanggung jawab jalannya suatu perusahaan atau organisasi. Dalam Islam, secara jelas dan tegas, manusialah yang menjadi pengganti dan wakil Allah Swt. di muka bumi ini untuk memakmurkannya sesuai dengan aturan dan ketentuan Allah Swt. Oleh karena itu tidak ada alasan untuk melarikan diri dari tanggung jawab ini kendatipun membuat lembaga atau organisasi di bidang bisnis dan politik. Islam menempatkan semua dalam satu kesatuan yang tidak terpisahkan satu sama lain atau integrated. (Harahap, 2011: 104)

Penanggungjawab jalannya kegiatan usaha dan operasional Rumah Yoghurt terletak pada struktur organisasi tertinggi pada perusahaan yaitu direktur. Meskipun secara garis besar setiap karyawan yang terlibat aktif dalam kegiatan usaha Rumah Yoghurt bertanggungjawab atas hak dan kewajibannya masing-masing sesuai dengan tingkatan struktur orginasasinya, direktur tetap menjadi penanggungjawab utama.

Terkait dengan sistem manajemen yang diterapkan oleh Rumah Yoghurt yaitu, melaksanakan praktik sumber daya manusia yang adil, memberikan hak-hak karyawan, dan memberikan reward berdasarkan kinerja, upaya, kreasi, dan keunggulannya sudah menjadi tradisi sejak awal berdiri perusahaan. Karena masing-masing karyawan meyakini hubungan yang baik antar sesama karyawan dapat menciptakan lingkungan kerja yang kondusif, sehingga tingkat produktivitas karyawan pun meningkat. Dalam menciptakan lingkungan kerja yang kondusif diperlukan pula arahan dan motivasi pimpinan kepada para karyawan, sehingga karyawan lebih merasakan sense of belonging serta bertanggung jawab penuh terhadap tugastugas yang dipercayakan kepadanya. Berkata santun dan lemah lembut merupakan prasyarat pertama dan utama jika ingin komunikasi efektif dan mencapai sasaran.

Strategi pengembangan sumber daya manusia yang dilakukan meliputi merencanakan dan merekrut sumber daya manusia yang berkualitas, mengembangkan, menilai kinerja, memberikan motivasi, dan memelihara sumberdaya manusia yang 
berkualitas. Hal tersebut nampak pada sering diadakannya pelatihan untuk para karyawan guna menambah ilmunya, khususnya dalam bidang industri susu. Sehingga pengetahuan karyawan, lebih khususnya karyawan bagian produksi dapat mengembangkan ilmunya hingga mampu membuat inovasi produk ataupun melakukan evaluasi terhadap produk yang dihasilkan Rumah Yoghurt. Pelatihan rutin yang diikuti karyawan berdampak positif terhadap pengembangan kualitas produk dikarenakan keahliannya semakin mumpuni untuk melakukan diversifikasi produk. Upaya pengembangan sumber daya manusia melalui pelatihan rutin tersebut merupakan usaha yang sengaja dilakukan untuk meningkatkan kinerja sekarang dan yang akan datang dengan meningkatkan kemampuan.

Perencanaan sumber daya manusia yang dilakukan Rumah Yoghurt mengacu pada Al Quran untuk menjadikan orang berlaku adil, berbuat kebajikan, memberikan bantuan, melarang kemungkaran, kekejian dan permusuhan seperti disebutkan dalam surat An Nahl ayat 90:

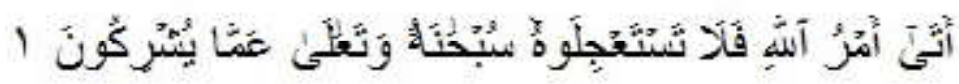

"Sesungguhnya Allah menyuruh (kamu) berlaku adil dan berbuat kebajikan, memberi kepada kaum kerabat dan Allah melarang dari perbuatan keji, kemungkaran, dan permusuhan. Dia memberi pengajaran kepadamu agar kamu dapat mengambil pelajaran."

\section{Etika Pemasaran}

Rumah Yoghurt memiliki beberapa pedoman dalam menerapkan etika pemasaran perusahaannya, yaitu: 


\section{Tabel 2. Pedoman Etika Pemasaran}

\begin{tabular}{|c|c|}
\hline No & Keterangan \\
\hline 1 & Menerapkan sistem promosi yang objektif \\
\hline 2 & Memilih orang yang tepat sesuai keahliannya \\
\hline 3 & Tidak melakukan manipulasi informasi dan promosi \\
\hline 4 & $\begin{array}{l}\text { Bersikap baik budi, jujur, amanah, tidak boleh menipu, memeras, merampas, dan } \\
\text { semena-mena }\end{array}$ \\
\hline 5 & Mempromosikan persaudaraan, kerja sama, dan kasih sayang \\
\hline 6 & Berupaya terus memberikan kemudahan, bukan mempersulit orang lain \\
\hline 7 & $\begin{array}{l}\text { Tidak melakukan upaya marketing yang bersifat "menggoda" yang mengarah } \\
\text { pada keterpaksaan membeli jasa dan barang yang ditawarkan }\end{array}$ \\
\hline 8 & Tidak melakukan manipulasi harga walaupun memiliki kemampuan untuk itu \\
\hline 9 & $\begin{array}{l}\text { Memberikan kebebasan kepada konsumen untuk mengembalikan barang yang } \\
\text { tidak disukai akibat kesalahan atau tidak sesuai dengan keinginannya }\end{array}$ \\
\hline 10 & Memberikan jaminan pelayanan purnajual secara jujur \\
\hline 11 & $\begin{array}{l}\text { Memberikan jasa atau memproduksikan barang yang dibolehkan dalam syariat } \\
\text { Islam }\end{array}$ \\
\hline 12 & $\begin{array}{l}\text { Menetapkan harga sesuai dengan ekspektasi laba yang normal dan tidak } \\
\text { merugikan masyarakat }\end{array}$ \\
\hline 13 & $\begin{array}{l}\text { Tidak menetapkan harga sebelum pihak terkait mengetahui situasi atau informasi } \\
\text { pasar }\end{array}$ \\
\hline
\end{tabular}

Sumber: Rumah Yoghurt Kota Batu, 2010

Dalam kajian fiqih Islam, kebenaran dan keakuratan informasi ketika seorang pelaku usaha mempromosikan barang dagangannya menempati kajian yang sangat signifikan. Islam tidak mengenal sebuah istilah kapitalisme klasik yang berbunyi "ceveat emptor" atau "let the buyer beware" (pembelilah yang harus berhatihati), tidak pula "ceveat venditor" (pelaku usahalah yang harus berhati-hati). Tetapi dalam Islam yang berlaku adalah prinsip keseimbangan ( $a l$-ta 'adul) atau ekuilibrium di mana pembeli dan penjual harus berhati-hati di mana hal itu tercermin dalam teori perjanjian (nazhariyyat al- 'uqud) dalam Islam. (Djakfar, 2007:83)

Strategi pemasaran yang dilakukan Rumah Yoghurt meliputi segmentasi pasar dan membidik pasar, strategi produk, strategi harga, strategi tempat, dan strategi promosi. Segmentasi pasar bermanfaat untuk mengklasifikan manfaat yang terkandung dalam suatu produk. Konsumen akan mencari produk yang menyediakan manfaat khusus untuk memuaskan kebutuhannya. Setelah melakukan segmentasi pasar, langkah berikutnya ialah membidik segmen pasar terbaik. Dalam hal ini termasuk juga menentukan pesaing, mengenali keunggulan pesaing yang mungkin untuk dimanfaatkan, dan merancang citra perusahaan serta kualitas produk yang ditawarkan sehingga pelanggan dalam suatu segmen memahami keunggulan produk perusahaan apabila dibandingkan dengan produk lain. Strategi produk yang dilakukan oleh Rumah Yoghurt ialah memprioritaskan kualitas produk agar tetap terjaga, dimana kualitas tersebut didefinisikan oleh pelanggan. Kualitas merupakan seberapa baik sebuah produk sesuai dengan kebutuhan spesifik dari pelanggan. Keistimewaan 
produk yang diberikan perusahaan kepada pelanggan ialah kemurnian dan keanekaragaman produk Rumah Yoghurt. Hal tersebut menjadikan produk Rumah Yoghurt lebih diminati pelanggan dibandingkan dengan kebanyakan produk perusahaan lain yang dalam komposisi produknya menggunakan campuran bahan kimia terlalu banyak.

Kemurnian dan kualitas produk dijadikan perusahaan sebagai prioritas utama guna memenuhi kebutuhan pelanggan, hal tersebut mengacu pada Al Quran sebagaimana dinyatakan di dalamnya dengan dua istilah, yaitu al-tayyibat dan alrizq. Kata al-tayyibat digunakan 18 kali, sedangkan kata al-rizq digunakan 120 kali. Al-tayyibat merujuk pada suatu yang baik, suatu yang murni dan baik, sesuatu yang bersih dan murni, sesuatu yang baik dan menyeluruh serta makanan yang terbaik. Al-rizq merujuk pada makanan yang diberkahi Tuhan, pemberian yang menyenangkan dan ketetapan Tuhan. (Ali, 1975 dalam Suyanto 2008:263)

Menurut Islam, produk konsumen adalah berdayaguna, materi yang dapat dikonsumsi, yang bermanfaat, yang bernilai guna, yang menghasilkan perbaikan material, moral, spiritual bagi konsumen. (Suyanto 2008:263)

Strategi pemasaran yang dilakukan perusahaan tidak hanya pada jaminan kualitas produk yang dimiliki, namun juga pada tata cara memperlakukan pelanggan. Pelayanan pada pelanggan yang memang diingini oleh para pelanggan mulai dari individu hingga restoran besar.

Terlepas dari seberapa besarnya hasil penjualan yang dapat diraih, perusahaan juga mengutamakan keberkahan kegiatan usahanya. Dari Abu Hurairah, RA, katanya dia mendengar Rasulullah SAW bersabda: "Sumpah itu melariskan dagangan, tetapi menghapuskan keberkahan” (Bukhari). Keberkahan juga dapat diperoleh jika menimbang atau menakar dalam jual beli. Dari Miqdam bin Ma'diytakriba, RA, dari Nabi SAW, sabdanya: "Gantanglah (timbanglah) makananmu, kamu akan diberi berkah” (Bukhari).

\section{Etika Lingkungan}

Rumah Yoghurt memiliki beberapa pedoman dalam menerapkan etika lingkungan perusahaannya, yaitu: 


\section{Tabel 3. Pedoman Etika Lingkungan}

\begin{tabular}{ll}
\hline No & Keterangan \\
\hline 1 & Membayar zakat, infaq, dan sedekah \\
2 & $\begin{array}{l}\text { Harus ditanamkan kesadaran bahwa Allah selalu melihat, mengontrol setiap } \\
\text { perbuatan kita }\end{array}$ \\
3 & $\begin{array}{l}\text { Dilarang mengeksploitasi seseorang atau binatang dalam kerja } \\
\text { Tidak melakukan bisnis yang dilarang Allah, seperti bisnis minuman keras, }\end{array}$ \\
& $\begin{array}{l}\text { riba, prostitusi, pembunuhan, dan lain-lain } \\
5\end{array}$ \\
6 & Menciptakan lingkungan atau budaya bisnis yang sesuai syariat \\
7 & Penghapusan perlakuan diskriminasi terhadap pekerja \\
8 & Harus mencegah kerusakan lingkungan hidup dan mengambil inisiatif \\
9 & Mntuk melestarikan
\end{tabular}

Sumber: Rumah Yoghurt Kota Batu, 2010

Islam tidak mengakui keberadaan sebuah usaha sebagai entitas perusahaan legal yang pemiliknya tidak bertanggung jawab secara pribadi terhadap berbagai masalah yang diciptakannya. Karenanya, jika sebuah usaha menciptakan masalah, maka pemiliknya harus siap untuk menyelesaikannya. (Muhammad, 2002:195)

Aktivitas bisnis saat ini tidak lagi dihadapkan pada tanggungjawab yang berpijak pada single bottom line, yang direfleksikan dalam kondisi keuangannya (financial) saja. Tapi tanggung jawab perusahaan harus berpijak pada triple bottom lines. Di sini bottom lines lainnya selain finansial juga ada sosial dan lingkungan, karena kondisi keuangan saja tidak cukup menjamin nilai perusahaan tumbuh secara berkelanjutan (sustainable). Keberlanjutan perusahaan hanya akan terjamin apabila perusahaan memperhatikan dimensi sosial dan lingkungan hidup. Sudah menjadi fakta bagaimana resistensi masyarakat sekitar, di berbagai tempat dan waktu muncul ke permukaan terhadap perusahaan yang dianggap tidak memperhatikan aspekaspek sosial, ekonomi dan lingkungan hidupnya.

Di samping memberi hak dan memelihara kehidupan karyawan Rumah Yoghurt, perusahaan turut serta memelihara lingkungan hidup di sekitar perusahaan dengan menangani limbah secara bijak. Proses produksi perusahaan yang meliputi produksi keju mozzarella dan yoghurt tergolong ramah lingkungan, dikarenakan limbah yang dihasilkan keju mozzarella berupa zat cair tanpa kandungan kimia yang dapat dimanfaatkan sebagai pupuk kandang. Sedangkan dalam proses produksi yoghurt tidak menghasilkan limbah apapun. Lingkungan hidup yang berada di sekitar wilayah Rumah Yoghurt bukan saja lingkungan alam, namun juga penduduk sekitar perusahaan. Kontribusi nyata Rumah Yoghurt dalam memperhatikan kesejahteraan masyarakat sekitar ialah rekruitmen karyawan perusahaan yang lebih memprioritaskan masyarakat sekitar sesuai dengan kualitas yang dimiliki. 
Apabila penanganan limbah yang ramah lingkungan serta aktivitas sosial perusahaan dilakukan secara berkelanjutan, perusahaan akan memiliki citra baik dalam perspektif pelanggan. Karena modern ini masyarakat cenderung memilih produk yang ramah akan lingkungan. Hal tersebut dimanfaatkan baik oleh Rumah Yoghurt, karena tidak bisa dipungkiri bahwa dengan melakukan aktivitas sosial, bisa dijadikan sebagai alat marketing baru bagi perusahaan. Produk semakin diminati dan loyalitas pelanggan semakin tinggi. Seiring meningkatnya loyalitas konsumen dalam waktu yang lama, maka penjualan perusahaan akan semakin membaik, dan pada akhirnya diharapkan tingkat profitabilitas perusahaan juga meningkat.

\section{SIMPULAN}

Berdasarkan kajian dan analisis yang dilakukan mengenai penerapan etika bisnis Islam terhadap tingkat profitabilitas perusahaan dalam perspektif karyawan, kesimpulan yang dapat diambil adalah sebagai berikut:

1. Penerapan etika bisnis Islam oleh Rumah Yoghurt berlandaskan pada pemahaman bahwa manusia merupakan wakil Allah Swt. di bumi yang diberikan kenikmatan tak terhitung dan bertanggungjawab atas segala perbuatannya. Dalam menjalankan aktivitas bisnisnya, Rumah Yoghurt memiliki pedoman usaha yang berisikan pemahaman mengenai pertanggungjawaban tidak hanya pada dirinya, namun juga lingkungan sosial dan lingkungan hidup. Dengan pemahaman tersebut, Rumah Yoghurt mengukur keberhasilan usahanya tidak pada aspek finansialnya saja, namun juga keberkahan usaha. Sehingga tidak hanya memberikan manfaat bagi perusahaan, namun juga bagi konsumen serta lingkungan sekitar perusahaan. Apabila dilihat pada skor hasil penyebaran kuisioner, karyawan beranggapan bahwa perusahaan menjalankan aktivitas bisnisnya sesuai dengan syariat dan pedoman pada aspek etika manajemen, etika pemasaran, dan etika lingkungan.

2. Etika bisnis Islam yang diterapkan oleh Rumah Yoghurt dinilai oleh sebagian besar karyawan efektif dalam meningkatkan profitabilitas perusahaan. Hal ini dibuktikan dari keseluruhan rata-rata skor hasil kuisioner karyawan yang tinggi baik pada aspek etika manajemen, etika pemasaran, maupun etika lingkungan. Dalam menjalankan kegiatan usaha dan operasionalnya, Rumah Yoghurt memiliki standar pedoman etika bisnis Islam yang melandasi seluruh kegiatan usaha dan operasional perusahaan. Apabila perusahaan dapat menerapkan pedoman etika bisnis Islam tersebut dengan baik dan secara berkelanjutan, maka diyakini oleh sebagian besar karyawan, tingkat profitabilitas perusahaan akan meningkat. 


\section{DAFTAR PUSTAKA}

Ananda, Fitra. 2011. Analisis Perkembangan Usaha Mikro Dan Kecil Setelah Memperoleh Pembiayaan Mudharabah Dari BMT At Taqwa Di Kota Semarang. Skripsi. Semarang: FE-UNDIP.

Antonio, Syafi’i Muhammad. 2001. Bank Syariah Dari Teori Ke Praktik. Jakarta: Gema Insani Press.

Amalia, Fitri. 2011. Penerapan Etika Bisnis Islam Bagi Pelaku Usaha Industri Kreatif(Studi kasus pada Kampoeng Kreatif). Skripsi. Jakarta: FE-UIN Syarif.

Buchori, Imam. 2013. Pengaruh Tingkat Pembiayaan Mudharabah Terhadap Tingkat Rasio Profitabilitas Pada Koperasi Jasa Keuangan Syariah (KJKS) Manfaat Surabaya. Buletin El Qits, Vol.03. No.1, April 2013.

Dahli, L., dan Siregar, V.S. 2008. Pengaruh Corporate Social Responsibility terhadap Kinerja Perusahaan (Studi Empiris pada Perusahaan yang tercatat di Bursa Efek Indonesia pada Tahun 2005 dan 2006). Simposium Nasional Akuntansi XI. Pontianak.

Erni, dan Ernawan. 2007. Business Ethics. Bandung: Alfabeta.

Juliansyah, Hafiz. 2011. Penerapan Etika Bisnis Islam Pedagang di Pasar Ciputat. Skripsi. Jakarta: FE UIN Syarif.

Husnan, Suad. 1995. Manajemen Keuangan Teori dan Penerapan Keputusan Jangka Pendek. Yogyakarta: Badan Penerbit UGM.

Hernanda, Tito. 2012. Perkembangan Usaha Kecil dan Menengah Sektor Peternakan Sapi Perah. Dalam http://infoukm.wordpress.com/. Diakses pada tanggal 12 Maret 2014.

Ichwan, Nur. 2011. Efektivitas Pembiayaan Mudharabah dalam Kinerja Finansial Koperasi Al Haromain Bantul Yogyakarta. Dalam http://muslim.or.id. Diakses pada tanggal 12 Maret 2014.

Kasmir. 2008. Analisis Laporan Keuangan. Jakarta: Rajawali Pers.

Muhammad. 2005. Pengantar Akuntansi Syariah. Edisi 2. Jakarta: Salemba Empat.

Qardhawi, Yusuf. 1999. Fiqh Az-Zakat (terj. Didin H. Dkk). Bandung: Mizan.

Rimba Kusumadilaga (2010, Pengaruh Corporate Social Responsibility Terhadap Nilai Perusahaan Dengan Profitabilitas Sebagai Variabel Moderating). Skripsi. Semarang: FE-UNDIP.

Syamsuddin, Lukman. 2009. Manajemen Keuangan Perusahaan: Konsep Aplikasi dalam Perencanaan, Pengawasan, Dan Pengambilan Keputusan. Edisi Baru. Jakarta: Raja Grafindo Persada.

Sulaiman, Muhammad. 2010. Jejak Bisnis Rasul. Jakarta: Hikmah ( PT Mizan Publika).

Sriyana, Jaka. 2010. Strategi Pengembangan Usaha Kecil Dan Menengah (UKM): Studi Kasus Di Kabupaten Bantul. Jurnal Bisnis Keuangan dan Akuntansi.

Suyanto, M. 2008. Muhammad Business Strategy And Ethics. Yogyakarta: Andi.

Yanuarto, Eko dan Kumorohadi, Untung. 2012. Peran Kapabilitas Inovasi Terhadap Perbaikan Produk Usaha Kecil Menengah (UKM) Dengan Tekanan Lingkungan Dan Ukuran Perusahaan Sebagai Variabel Moderasi (Studi pada UKM di Kabupaten Purbalingga). Jurnal Bisnis Keuangan dan Akuntansi.

El-Muhasaba, Vol. 7, No 2, Juli 2016 